\title{
Penilaian Kesehatan Keuangan Koperasi Berdasarkan Peraturan Deputi Bidang Pengawasan Kementerian Koperasi dan UKM RI Nomor: 07/PER/DEP.6/IV/2016 pada KSPPS Tanah Sirah Piai Nan XX Kota Padang Periode 2016-2018
}

\author{
Dwila Maresti ${ }^{1}$, Sriwahyuni Riza ${ }^{2}$ \\ 1,2Universitas Andalas, Padang Sumatera Barat \\ Correspondence email: dwilamaresti86@gmail.com
}

\begin{abstract}
The purpose of this study was to determine the level of health of a Savings and Loan Cooperative and Sharia Financing (KSPPS) in one of the Padang City sub-districts namely Tanah Sirah Piai Nan XX in 3 (three) years of operation. The research is intended to help the Padang City Cooperative Office to find out the health condition of cooperatives in the Padang City area as well as the KSPPS Cooperative to find out the health of cooperatives managed. Based on quantitative research with a descriptive approach, this health assessment analysis refers to the Regulation of the Deputy for Supervision of the Ministry of Cooperatives and Small and Medium Enterprises of the Republic of Indonesia Number 07 / Per / Dep.6 / IV / 2016 concerning Guidelines on Health Assessment for Savings and Loans Cooperatives and Sharia Financing and Units Savings and Credit Sharia Financing. The results showed the health level of KSPPS Tanah Sirah Piai XX was concluded that KSPPS Tanah Sirah Piai Nan XX was quite healthy.
\end{abstract}

Keywords: KSPPS; Healthy Cooperative; Healthy assessment

\section{PENDAHULUAN}

Koperasi Simpan Pinjam dan Pembiayaan Syariah (yang selanjutnya disebut KSPPS) adalah koperasi yang kegiatan usahanya berupa simpan, pinjam dan pembiayaan sesuai dengan prinsip syariah. Koperasi yang melaksanakan kegiatan dengan prinsip syariah ini wajib memiliki unit kegiatan sosial (maal) dan unit usaha kegiatan bisnis (tamwil). Perwujudan dari kesungguhan KSPPS ini dalam mengelola dana masyarakat adalah dengan menjaga kesehatan kinerjanya. Kesehatan kinerja bagi suatu lembaga usaha sangat penting. Diketahuinya tingkat kesehatan suatu usaha, masyarakat (anggota) dapat dengan mudah menilai kinerja lembaga tersebut. Koperasi yang tidak sehat, bukan hanya membahayakan dirinya sendiri, akan tetapi pihak lain. Keberhasilan atau tidaknya suatu koperasi tergambar dari kinerja para pengurus dan pengelola dalam meningkatkan keuangan koperasi dan ter record dalam laporan keuangan. Salah satu cara dapat dilakukan manajemen untuk mengetahui kewajibannya terhadap pemilik dana dan untuk mencapai tujuan yang telah ditetapkan oleh lembaga adalah dengan melakukan penilaian atas kinerja keuangan. Kinerja keuangan dalam suatu koperasi dapat diketahui dengan cara menganalisis hubungan dari setiap pos dalam laporan keuangan.

Dalam rangka meningkatkan kualitas penilaian kinerja koperasi dan meningkatkan hasil penilaian kinerja sebagai dasar bagi koperasi untuk mengakses pembiayaan usaha dari lembaga-lembaga pembiayaan, maka Kementerian Koperasi dan UKM menetapkan peraturan koperasi melalui Peraturan Deputi Bidang Pengawasan Kementerian Koperasi dan UKM RI Nomor 02/PER/DEP.6/III/2016 tentang Pedoman Penilaian Kesehatan KSPPS dan USPPS yang kemudian diperbaharui melalui Peraturan Deputi Bidang Pengawasan Kementerian Koperasi dan UKM RI Nomor 07/PER/DEP.6/IV/2016. Penilaian kesehatan seluruh KSPPS kelurahan yang ada di Kota Padang telah diteliti oleh Wira \& Gustati (2016). Tujuan penelitian Wira \& Gustati (2016) adalah menganalisis komponen penilaian kesehatan yang dihubungkan dengan predikat tingkat kesehatan KSPPS. Hasil yang ditemukan secara umum, untuk mencapai predikat sehat, KSPPS harus memiliki kepercayaan penuh dari anggotanya dalam halpenyimpanandana mereka di KSPPS. Perbedaan penelitian ini dengan penelitian Wira \& Gustati (2016), pada penelitian ini lebih terfokus pada satu KSPPS, sehingga hasil yang didapat nantinya lebih terinci dan jelas.

KSPPS Tanah Sirah Piai Nan XX Kota Padang merupakan koperasi kelurahan di lingkungan Kecamatan Lubuk Begalung Kota Padang. KSPPS Tanah Sirah Piai Nan XX, dalam pengelolaan dananya telah berorientasi pada keputusan kementerian tersebut, namun belum seluruhnya dilaksanakan, mengingat dalam pengelolaan keuangannya disamping belum memiliki Dewan Pengawas Syariah, juga adanya tunggakan dari anggota dalam membayar pembiayaan yang telah diberikan sehingga pelaksanaan keuangan koperasi agak sedikit terlambat dalam penyelesaiannya dan keuangan koperasi tersebut dilakukan oleh anggota koperasi yang pada umumnya masyarakat kelurahan sendiri. Penataan akuntansi keuangan koperasi yang dilaksanakan oleh KSPPS Tanah Sirah Piai Nan XX, masih terdapat kekurangan dalam menerapkan Keputusan Menteri, sehingga masih memerlukan 
penyempurnaan, tetapi dalam laporan pertanggungjawaban keuangan telah menunjukkan keadaan keuangan yang sederhana yang baik tanpa melihat rasio keuangan berdasarkan keputusan tersebut. Berdasarkan permasalahan diatas, penelitian ini perlu dilakukan dengan tujuan untuk menganalisis dan melakukan penilaian kesehatan keuangan KSPPS Tanah Sirah Piai Nan XX berdasarkan Peraturan Deputi Bidang Pengawasan Kementerian Koperasi dan UKM RI Nomor : 07/Per/Dep.6/IV/2016. Kontribusi yang diharapkan dalam penelitian ini adalah memberikan masukan kepada pengurus KSPPS dan Dinas Koperasi dan UKM untuk lebih memperhatikan komponen kesehatan yang kritis dalam penilaian kesehatan KSPPS.

Pengertian Koperasi Menurut undang-undang Perkoperasian Nomor 25 tahun 1992 menyatakan "Koperasi adalah badan usaha yang beranggotakan orang-seorang atau badan hukum koperasi dengan melandaskan segala kegiatannya berdasarkan prinsip koperasi sekaligus sebagai gerakan ekonomi rakyat yang berdasarkan atas asas kekeluargaan".Koperasi tidak terlepas dari kegiatan operasi yang dimilikinya. KSPPS adalah koperasi yang kegiatan usahanya hanya simpan pinjam dan pembiayaan syariah termasuk mengelola zakat, infaq/sedekah, dan wakaf. Mengingat bidang usaha yang berasaskan kekeluargaan dan sesuai dengan budaya bangsa Indonesia terutama lapisan masyarakat yang menjunjung kebersamaan maka dalam usaha bersama, koperasi merupakan wadah yang tepat karena selain aspek ekonomis sebagai watak usahanya, aspek sosial sebagai watak kebersamaan dan prinsip syariah sebagai tuntunannya. Berdasarkan penjelasan diatas dapat disimpulkan secara umum koperasi adalah badan usaha yang mengorganisir pemanfaatan dam pendayagunaan sumber ekonomi para anggotanya atas dasar prinsip-prinsip koperasi. Berdasarkan Peraturan Deputi Bidang Pengawasan Kementerian Koperasi dan UKM RI Nomor : 07/Per/Dep.6/IV/2016 pada pasal 5 ruang lingkup penilaian kesehatan KSPPS dan USPPS koperasi dilakukan terhadap aspek sebagai berikut:Permodalan;Kualitas aktiva produktif; Manajemen; Efisiensi; Likuiditas; Kemandirian dan pertumbuhan; dan Jati diri koperasi; Kepatuhan Syariah. Pasal 7 dipergunakan untuk menetapkan predikat tingkat kesehatan KSPPS dan USPPS Koperasi yang dibagi dalam 4 (empat) golongan yaitu: (1) Sehat, jika skor penilaian sama dengan 80 sampai100; (2) Cukup Sehat, jika skor penilaian sama dengan 66 sampai lebih kecil dari 80; (3) Dalam Pengawasan, jika skor penilaian sama dengan 51 sampai lebih kecil dari 66; (4) Dalam Pengawasan Khusus, jika skor penilaian sama dengan kecil dari 51.

\section{METODE}

Populasi dan sampel dalam penelitian ini adalah tingkat kesehatan dari KSPPS Tanah Sirah Piai Nan XX Kota Padang. Pendekatan yang digunakan dalam penelitian ini adalah pendekatan kuantitatif deskriptif yaitu dengan menganalisis dan mendiskripsikan data-data laporan keuangan untuk menentukan kategori kesehatan KSPPS. Lokasi penelitian KSPPS Tanah Sirah Piai Nan XX Kota Padang. Sumber data sekunder yang digunakan laporan keuangan diantaranya Neraca, Laporan Rugi/Laba dan SHU dari tahun 2016-2018. Analisa data untuk mengetahui kesehatan KSPPS Tanah Sirah Piai Nan XX Kota Padang ada delapan aspek sesuai dengan Peraturan Deputi Bidang Pengawasan Kementerian Koperasi dan UKM RI Nomor: 07/Per/Dep.6/IV/2016.

\section{HASIL}

\section{Rasio Modal Sendiri terhadap Total Aset}

Rasio modal sendiri terhadap total aset ini dimaksudkan untuk mengukur kemampuan modal tetap "KSPPS Tanah Sirah Piai Nan XX Kota Padang" dalam mendukung pendanaan terhadap total aset. Setelah besarnya rasio diketahui, langkah selanjutnya yaitu pemberian skor terhadap rasio tersebut sesuai dengan Peraturan Deputi Bidang Pengawasan Kementerian Koperasi Dan UKM tahun 2016. Untuk skor rasio modal sendiri terhadap total aset di "KSPPS Tanah Sirah Piai Nan XX Kota Padang" tahun 2016-2018 dapat dilihat dalam tabel 1. Hasil perhitungan menunjukkan selama tiga terakhir mempunyai nilai skor rasio modal terhadap aset sama.

Tabel 1

Standar Perhitungan Modal Sendiri terhadap Total Aset

\begin{tabular}{ccccc}
\hline Rasio Permodalan (\%) & Nilai & Bobot Skor (\%) & Skor & Kriteria \\
\hline 0 & 0 & 5 & 0 & $0-1,25$ Tidak Sehat \\
5 & 25 & 5 & 1,25 & $1,26-2,50$ Kurang Sehat \\
10 & 50 & 5 & 1,50 & $2,51-3,75$ Cukup Sehat \\
15 & 75 & 5 & 3,75 & $3,76-5,0$ Sehat \\
20 & 100 & 5 & 5,0 & \\
\hline
\end{tabular}

Sumber: Perdep No: 07/Per/Dep.6/IV/2016 
Dwila Maresti dan Sriwahyuni Riza, Penilaian Kesehatan Keuangan Koperasi Berdasarkan Peraturan Deputi Bidang Pengawasan Kementerian Koperasi dan UKM RI NOMOR: 07/PER/DEP.6/IV/2016 pada KSPPS Tanah Sirah Piai Nan XX Kota Padang Periode 2016-2018

Tabel 2

Skor Rasio modal Sendiri terhadap Total Aset KSPPS Tanah Sirah Piai Nan XX Kota Padang

\begin{tabular}{ccccc}
\hline Tahun & Rasio Permodalan (\%) & Nilai & Bobot Skor (\%) & Skor \\
\hline 2016 & 92,25 & 100 & 5 & 5,0 \\
2017 & 95,60 & 100 & 5 & 5,0 \\
2018 & 94,80 & 100 & 5 & 5,0 \\
\hline
\end{tabular}

Sumber : hasil penelitian diolah

KSPPS Tanah Sirah Piai Nan XX Kota Padang memiliki angka rasio modal sendiri terhadap total aset ratarata diatas 90\% (lebih dari 20\%) maka nilai kreditnya 100 dengan skor dan bobotnya 5. Ini berarti bahwa rasio modal sendiri terhadap total aset memiliki kriteria Sehat. KSPPS Tanah Sirah Piai Nan XX Kota Padang dapat menghimpun modal sendiri yang dimiliki yaitu terdiri dari bentuk simpanan pokok, simpanan wajib dan simpanan pendiri. Hal ini terjadi karena peningkatan kepercayaan masyarakat untuk melakukan kegiatan pembiayaan maupun simpanan pada KSPPS Tanah Sirah Piai Nan XX Kota Padang.

\section{Rasio Kecukupan Modal}

Tabel 3

Standar Perhitungan Rasio Kecukupan Modal (CAR)

\begin{tabular}{ccccl}
\hline Rasio Modal (\%) & Nilai & Bobot (\%) & Skor & Kriteria \\
\hline$<6$ & 25 & 5 & 1,25 & Tidak sehat \\
$6-<7$ & 50 & 5 & 2,50 & Kurang sehat \\
$7-<8$ & 75 & 5 & 3,75 & Cukup sehat \\
$\geq 8$ & 100 & 5 & 5,00 & Sehat \\
\hline
\end{tabular}

Sumber: Perdep No: 07/Per/Dep.6/IV/2016

Setelah besarnya rasio diketahui, langkah selanjutnya yaitu pemberian skor terhadap rasio tersebut sesuai dengan Peraturan Deputi Bidang Pengawasan KemenKo Dan UKM tahun 2016. Untuk skor rasio kecukupan modal (CAR) di "KSPPS Tanah Sirah Piai Nan XX Kota Padang" tahun 2016-2018 dapat dilihat dalam tabel 4 Hasil perhitungan menunjukkan selama tiga tahun terakhir mempunyai nilai skor rasio modal tertimbang terhadap ATMR lebih dari ketentuan $8 \%$. Ini berarti bahwa rasio kecukupan modal memiliki kriteria Sehat

Tabel 4

Skor Rasio Kecukupan Modal (CAR)

\begin{tabular}{ccccc}
\hline Tahun & Rasio Permodalan $(\%)$ & Nilai & Bobot Skor $(\boldsymbol{\%})$ & Skor \\
\hline 2016 & 95,35 & 100 & 5 & 5,0 \\
2017 & 110,25 & 100 & 5 & 5,0 \\
2018 & 102,21 & 100 & 5 & 5,0 \\
\hline
\end{tabular}

Sumber : olahan data

Rasio Kualitas Aktiva Produktif

Rasio Piutang dan Pembiayaan Bermasalah terhadap Piutang dan Pembiayaan yang Diberikan

Tabel 5

Standar Perhitungan Rasio Piutang dan Pembiayaan Bermasalah terhadap piutang dan Pembiayaan yang Diberikan

\begin{tabular}{cccc}
$\begin{array}{c}\text { Rasio Pembiayaan Bermasalah terhadap } \\
\text { Pembiayaan yang Diberikan }(\boldsymbol{\%})\end{array}$ & Bobot $(\boldsymbol{\%})$ & Skor & Kriteria \\
\hline$>12$ & 10 & 2,50 & Tidak lancar \\
$9-12$ & 10 & 5,00 & Kurang lancar \\
$5-8$ & 10 & 7,50 & Cukup lancar \\
$<5$ & 10 & 10,00 & Lancar \\
\hline
\end{tabular}

Sumber: Perdep No: 07/Per/Dep.6/IV/2016

Untuk skor rasio piutang dan pembiayaan bermasalah terhadap piutang dan pembiayaan yang diberikan di "KSPPS Tanah Sirah Piai Nan XX Kota Padang" tahun 2016-2018 dapat dilihat dalam tabel 6. Hasil perhitungan menunjukkan selama tiga tahun terakhir mempunyai nilai skor yang bervariasi dan penurunan terlihat ditahun 2018 . 
Dwila Maresti dan Sriwahyuni Riza, Penilaian Kesehatan Keuangan Koperasi Berdasarkan Peraturan Deputi Bidang Pengawasan Kementerian Koperasi dan UKM RI NOMOR: 07/PER/DEP.6/IV/2016 pada KSPPS Tanah Sirah Piai Nan XX Kota Padang Periode 2016-2018

Tabel 6

Rasio Piutang dan Pembiayaan Bermasalah terhadap Piutang dan Pembiayaan yang Diberikan

\begin{tabular}{ccccc}
\hline Tahun & $\begin{array}{c}\text { Rasio Pembiayaan Bermasalah } \\
\text { terhadap Pembiayaan yang Diberikan }(\%)\end{array}$ & Nilai & Bobot & Skor \\
\hline 2016 & 18,15 & 25 & 10 & 2,5 \\
2017 & 4,85 & 100 & 10 & 10,00 \\
2018 & 34,32 & 25 & 10 & 2,5 \\
\hline
\end{tabular}

Sumber : olahan data

\section{Rasio Portofolio Pembiayaan Beresiko}

Tabel 7

Standar Perhitungan Rasio Portofolio Beresiko

\begin{tabular}{ccccl}
\hline Rasio Portofolio Beresiko (\%) & Nilai & Bobot $(\boldsymbol{\%})$ & Skor & Kriteria \\
\hline$>30$ & 25 & 5 & 1,25 & Sangat Beresiko \\
$26-30$ & 50 & 5 & 2,50 & Kurang Beresiko \\
$21-<26$ & 75 & 5 & 3,75 & Cukup Beresiko \\
$<21$ & 100 & 5 & 5,00 & Tidak Beresiko \\
\hline
\end{tabular}

Sumber: Perdep No: 07/Per/Dep.6/IV/2016

Skor rasio portofolio beresiko yang diberikan di "KSPPS Tanah Sirah Piai Nan XX Kota Padang” tahun 2016 2018 dapat dilihat dalam tabel 8. Hasil perhitungan menunjukkan selama tiga tahun terakhir mempunyai nilai skor yang bervariasi.

Tabel 8

Rasio Portofolio Beresiko

\begin{tabular}{ccccc}
\hline Tahun & Rasio Portofolio Beresiko (\%) & Nilai & Bobot & Skor \\
\hline 2016 & 19,75 & 100 & 5 & 5,00 \\
2017 & 11,65 & 100 & 5 & 5,00 \\
2018 & 45,32 & 25 & 5 & 1,25 \\
\hline
\end{tabular}

Sumber : olahan data

Rasio Penyisihan Penghapusan Aktiva Produktif (PPAP)

Tabel 9

Standar Perhitungan Rasio Penghapusan Aktiva Produktif

\begin{tabular}{cccccc}
\hline Rasio PPAP $(\%)$ & Nilai Kredit & Bobot $(\boldsymbol{\%})$ & Skor & \multicolumn{1}{c}{ Kriteria } \\
\hline 0 & 0 & 5 & 0 & $0-<1,25$ & Macet \\
10 & 10 & 5 & 0,5 & $1,25-<2,5$ & Diragukan \\
20 & 20 & 5 & 1,0 & $2,5-<3,75$ & Kurang Lancar \\
30 & 30 & 5 & 1,5 & $3,75-5$ & Lancar \\
40 & 40 & 5 & 2,0 & \\
50 & 50 & 5 & 2,5 & \\
60 & 60 & 5 & 3,0 & \\
70 & 70 & 5 & 3,5 & \\
80 & 80 & 5 & 4,0 & \\
90 & 90 & 5 & 4,5 & \\
100 & 100 & 5 & 5,0 & \\
\hline
\end{tabular}

Sumber: Perdep No: 07/Per/Dep.6/IV/2016

Skor rasio penghapusan aktiva produktif yang diberikan di "KSPPS Tanah Sirah Piai Nan XX Kota Padang" tahun 2016-2018 dapat dilihat dalam tabel 10. Hasil perhitungan menunjukkan selama tiga tahun terakhir ditemukan di tahun 2017 KSPPS Tanah Sirah Piai Nan XX Kota Padang tidak menyisihkan pendapatannya untuk menutupi risiko (penghapusan) aktiva produktif 
Dwila Maresti dan Sriwahyuni Riza, Penilaian Kesehatan Keuangan Koperasi Berdasarkan Peraturan Deputi Bidang Pengawasan Kementerian Koperasi dan UKM RI NOMOR: 07/PER/DEP.6/IV/2016 pada KSPPS Tanah Sirah Piai Nan XX Kota Padang Periode 2016-2018

Tabel 10

Rasio Penghapusan Aktiva Produktif

\begin{tabular}{ccccc}
\hline Tahun & Rasio Portofolio Beresiko $(\boldsymbol{\%})$ & Nilai & Bobot & Skor \\
\hline 2016 & 128,75 & 100 & 5 & 5,00 \\
2017 & 0 & 0 & 5 & 0,00 \\
2018 & 226,28 & 100 & 5 & 5,00 \\
\hline
\end{tabular}

Sumber : olahan data

\section{Penilaian Manajemen \\ Manajemen Umum}

Manajemen umum dinilai dengan mengajukan 12 pertanyaan dengan bobot 0,25 untuk setiap jawaban pertanyaan positif. Untuk setiap jawaban pertanyaan "iya" berarti jawaban positif dengan nilai 1, dan untuk setiap jawaban pertanyaan "tidak" berarti jawaban negatif dengan nilai 0. Setelah semua jawaban diperoleh, langkah selanjutnya yaitu pemberian skor terhadap jawaban tersebut sesuai dengan Peraturan Deputi Bidang Pengawasan Kementerian Koperasi Dan UKM tahun 2016. Untuk skor penilaian manajemen umum yang diberikan di "KSPPS Tanah Sirah Piai Nan XX Kota Padang" tahun 2016-2018 dapat dilihat dalam tabel 11. Hasil penilaian menunjukkan selama tiga tahun terakhir ditemukan KSPPS Tanah Sirah Piai Nan XX Kota Padang memperoleh rata-rata skor 3,00.Hal ini dikarenakan KSPPS Tanah Sirah Piai Nan XX Kota Padang dapat menjalankan semua fungsi manajemen umum dengan baik. Pertanyaan yang diajukan rata-rata mendapatkan nilai positif 1 sehingga memperoleh nilai yang baik pada total skor akhir.

Tabel 11

Penilaian Manajemen Umum

\begin{tabular}{ccccc}
\hline Tahun & Bobot & Skor & Kriteria \\
\hline 2016 & 2,5 & 2,50 & Baik \\
2017 & 3 & 3,00 & Baik \\
2018 & 3 & 3,00 & Baik \\
\hline
\end{tabular}

Sumber : olahan data

\section{Kelembagaan}

Tabel 12

Standar Penilaian Kelembagaan

\begin{tabular}{cccc}
\hline Positif & Nilai Kredit Bobot & Skor & Kriteria \\
\hline 1 & 0,50 & $0-0,75$ & Tidak Baik Kurang \\
3 & 1,00 & $0,76-1,50$ & Baik Cukup Baik Baik \\
4 & 1,50 & $1,51-2,25$ & \\
5 & 2,00 & $2,26-3,00$ & \\
6 & 2,50 & & \\
\hline
\end{tabular}

Sumber: Perdep No: 07/Per/Dep.6/IV/2016

Setelah semua jawaban diperoleh, langkah selanjutnya yaitu pemberian skor terhadap jawaban tersebut sesuai dengan Peraturan Deputi Bidang Pengawasan Kementerian Koperasi Dan UKM tahun 2016. Untuk skor penilaian kelembagaan yang diberikan di "KSPPS Tanah Sirah Piai Nan XX Kota Padang" tahun 2016-2018 dapat dilihat dalam tabel 14. Hasil penilaian menunjukkan selama tiga tahun terakhir ditemukan KSPPS Tanah Sirah Piai Nan XX Kota Padang memperoleh rata-rata skor 3,00. Hal ini dikarenakan KSPPS Tanah Sirah Piai Nan XX Kota Padang dapat menjawab semua pertanyaan tentang kelembagaan dengan baik. Pertanyaan yang diajukan mendapatkan nilai positif 1 sehingga memperoleh nilai yang baik pada total skor akhir.

Tabel 13

Penilaian Kelembagaan

\begin{tabular}{cccc}
\hline Tahun & Bobot & Skor & Kriteria \\
\hline 2016 & 3 & 3,00 & Baik \\
2017 & 3 & 3,00 & Baik \\
2018 & 3 & 3,00 & Baik \\
\hline
\end{tabular}

Sumber : olahan data 
Dwila Maresti dan Sriwahyuni Riza, Penilaian Kesehatan Keuangan Koperasi Berdasarkan Peraturan Deputi Bidang Pengawasan Kementerian Koperasi dan UKM RI NOMOR: 07/PER/DEP.6/IV/2016 pada KSPPS Tanah Sirah Piai Nan XX Kota Padang Periode 2016-2018

\section{Manajemen Permodalan}

Tabel 14

Standar Penilaian Permodalan

\begin{tabular}{cccc}
\hline Positif & Nilai Kredit Bobot & Skor & Kriteria \\
\hline 1 & 0,60 & & Tidak Baik Kurang Baik \\
2 & 1,20 & $0-0,75$ & Cukup Baik Baik \\
3 & 1,80 & $0,76-1,50$ & \\
4 & 2,40 & $1,51-2,25$ & \\
5 & 3,00 & $2,26-3,00$ & \\
\hline
\end{tabular}

Sumber: Perdep No: 07/Per/Dep.6/IV/2016

Skor penilaian manajemen permodalan yang diberikan di "KSPPS Tanah Sirah Piai Nan XX Kota Padang" tahun 2016-2018 dapat dilihat dalam tabel 15. Hasil penilaian menunjukkan selama tiga tahun terakhir ditemukan KSPPS Tanah Sirah Piai Nan XX Kota Padang bervariasi. Hal ini dikarenakan tingkat pertumbuhan modal KSPPS Tanah Sirah Piai Nan XX Kota Padang semakin membaik dalam tiga tahun terakhir.

Tabel 15

Manajemen Permodalan

\begin{tabular}{cccc}
\hline Tahun & Bobot & Skor & Kriteria \\
\hline 2016 & 0,6 & 0,6 & Tidak Baik \\
2017 & 1,8 & 1,8 & Cukup Baik \\
2018 & 2,4 & 2,4 & Baik \\
\hline
\end{tabular}

Sumber : olahan data

Manajemen Aktiva

Tabel 16

Manajemen Aktiva

\begin{tabular}{cccc}
\hline Tahun & Bobot & Skor & Kriteria \\
\hline 2016 & 2,4 & 2,4 & Baik \\
2017 & 1,2 & 1,2 & Kurang Baik \\
2018 & 2,4 & 2,4 & Baik \\
\hline
\end{tabular}

Sumber : olahan data

\section{Manajemen Likuiditas}

Tabel 17

Standar Penilaian Manajemen Likuiditas

\begin{tabular}{cccc}
\hline Positif & Nilai Kredit Bobot & Skor & Kriteria \\
\hline 1 & 0,60 & $0-0,75$ & Tidak Baik Kurang Baik Cukup \\
2 & 1,20 & $0,76-1,50$ & Baik Baik \\
3 & 1,80 & $1,51-2,25$ & $2,26-3,00$ \\
5 & 2,40 & & \\
\hline
\end{tabular}

Sumber: Perdep No: 07/Per/Dep.6/IV/2016

Setelah semua jawaban diperoleh, langkah selanjutnya yaitu pemberian skor terhadap jawaban tersebut sesuai dengan Peraturan Deputi Bidang Pengawasan Kementerian Koperasi Dan UKM tahun 2016. Untuk skor penilaian manajemen likuiditas yang diberikan di "KSPPS Tanah Sirah Piai Nan XX Kota Padang" tahun 2016-2018 dapat dilihat dalam tabel 18. Hasil penilaian menunjukkan selama tiga tahun terakhir ditemukan KSPPS Tanah Sirah Piai Nan XX Kota Padang bervariasi. Hal ini dikarenakan tingkat likuiditas KSPPS Tanah Sirah Piai Nan XX Kota Padang pada tahun 2017 menurun dan kembali membaik pada tahun 2018. 
Dwila Maresti dan Sriwahyuni Riza, Penilaian Kesehatan Keuangan Koperasi Berdasarkan Peraturan Deputi Bidang Pengawasan Kementerian Koperasi dan UKM RI NOMOR: 07/PER/DEP.6/IV/2016 pada KSPPS Tanah Sirah Piai Nan XX Kota

Tabel 18

Manajemen Likuiditas

\begin{tabular}{cccc}
\hline Tahun & Bobot & Skor & Kriteria \\
\hline 2016 & 2,4 & 2,4 & Baik \\
2017 & 1,8 & 1,8 & Cukup Baik \\
2018 & 3,0 & 3,0 & Baik \\
\hline
\end{tabular}

Sumber : olahan data

\section{Rasio Efisiensi}

Rasio Biaya Operasional Pelayanan terhadap Partisipasi Bruto

Tabel 19

Standar Perhitungan Rasio Biaya Operasional Pelayanan terhadap Partisipasi Bruto

\begin{tabular}{ccccc}
\hline $\begin{array}{c}\text { Rasio Biaya Operasional Pelayanan } \\
\text { terhadap Partisipasi Bruto (\%) }\end{array}$ & Nilai & Bobot (\%) & Skor & Kriteria \\
\hline$>100$ & 25 & 4 & 1 & Tidak Efisien \\
$85-99$ & 50 & 4 & 2 & Kurang Efisien \\
$69-84$ & 75 & 4 & 3 & Cukup Efisien \\
$0-68$ & 100 & 4 & 4 & Efisien \\
\hline
\end{tabular}

Sumber: Perdep No: 07/Per/Dep.6/IV/2016

Setelah besarnya rasio diketahui, langkah selanjutnya yaitu pemberian skor terhadap rasio tersebut. Untuk skor rasio biaya operasional pelayanan terhadap partisipasi bruto di "KSPPS Tanah Sirah Piai Nan XX Kota Padang" tahun 2016-2018 dapat dilihat dalam tabel 20. Hasil perhitungan menunjukkan selama tiga tahun terakhir mempunyai nilai skor rasio lebih dari ketentuan efisien. Ini berarti bahwa rasio biaya operasional terhadap pelayanan terhadap partisipasi bruto yang dimiliki KSPPS Tanah Sirah Piai Nan XX Kota Padang besar dikarenakan belum mampu mengeluarkan biaya operasional yang minimum.

Tabel 20

Skor Rasio Biaya Operasional Pelayanan Terhadap Partisipasi Bruto

\begin{tabular}{ccccc}
\hline Tahun & $\begin{array}{c}\text { Rasio Biaya Operasional Pelayanan } \\
\text { terhadap Partisipasi Bruto (\%) }\end{array}$ & Nilai & Bobot Skor (\%) & Skor \\
\hline 2016 & 86,00 & 50 & 4 & 2,0 \\
2017 & 117,25 & 25 & 4 & 1,0 \\
2018 & 88,00 & 50 & 4 & 2,0 \\
\hline
\end{tabular}

Sumber : olahan data

Rasio Aktiva Tetap terhadap Total Asset

Tabel 21

Standar perhitungan Rasio Aktiva Tetap terhadap Total Asset

\begin{tabular}{ccccc}
\hline $\begin{array}{c}\text { Rasio Aktiva Tetap terhadap } \\
\text { Total Asset (\%) }\end{array}$ & Nilai & Bobot (\%) & Skor & Kriteria \\
\hline $76-100$ & 25 & 4 & 1 & Tidak Baik \\
$51-75$ & 50 & 4 & 2 & Kurang Baik \\
$26-50$ & 75 & 4 & 3 & Cukup Baik \\
$0-25$ & 100 & 4 & 4 & Baik \\
\hline
\end{tabular}

Sumber: Perdep No: 07/Per/Dep.6/IV/2016

Skor rasio aktiva tetap terhadap total asset di "KSPPS Tanah Sirah Piai Nan XX Kota Padang” tahun 2016 2018 dapat dilihat dalam tabel 22. Hasil perhitungan menunjukkan selama tiga tahun terakhir mempunyai nilai skor rasio ini mendapat kategori baik. Ini berarti bahwa rasio aktiva tetap terhadap total asset yang dimiliki KSPPS Tanah Sirah Piai Nan XX Kota Padang mampu memberikan pelayanan yang efisien kepada anggotanya dari penggunaan aset yang dimilikinya. 
Dwila Maresti dan Sriwahyuni Riza, Penilaian Kesehatan Keuangan Koperasi Berdasarkan Peraturan Deputi Bidang Pengawasan Kementerian Koperasi dan UKM RI NOMOR: 07/PER/DEP.6/IV/2016 pada KSPPS Tanah Sirah Piai Nan XX Kota Padang Periode 2016-2018

Tabel 22

Skor Rasio Aktiva Tetap terhadap Total Asset

\begin{tabular}{ccccc}
\hline Tahun & Rasio aktiva tetap terhadap total asset (\%) & Nilai & Bobot Skor (\%) & Skor \\
\hline 2016 & 6,00 & 100 & 4 & 4,0 \\
2017 & 4,25 & 100 & 4,0 & 4 \\
2018 & 3,73 & 100 & 4,0 \\
\hline
\end{tabular}

Sumber : olahan data

Rasio Efisiensi Pelayanan (Staf)

Tabel 23

Standar Perhitungan Rasio Efisiensi Staf

\begin{tabular}{ccccc}
\hline Rasio Efisiensi Staf (Orang) & Nilai & Bobot $(\%)$ & Skor & Kriteria \\
\hline$<50$ & 25 & 2 & 0,5 & Tidak Baik \\
$51-74$ & 50 & 2 & 1 & Kurang Baik \\
$75-99$ & 75 & 2 & 1,5 & Cukup Baik \\
$>99$ & 100 & 2 & 2 & Baik \\
\hline
\end{tabular}

Sumber: Perdep No: 07/Per/Dep.6/IV/2016

Setelah besarnya rasio diketahui, langkah selanjutnya yaitu pemberian skor terhadap rasio tersebut sesuai dengan Peraturan Deputi Bidang Pengawasan Kementerian Koperasi Dan UKM tahun 2016. Untuk skor rasio efisiensi staf di "KSPPS Tanah Sirah Piai Nan XX Kota Padang" tahun 2016-2018 dapat dilihat dalam tabel 24. Hasil perhitungan menunjukkan selama dua tahun pertama mempunyai nilai skor rasio ini mendapat kategori tidak baik. Ini berarti bahwa rasio efisiensi staf yang dimiliki KSPPS Tanah Sirah Piai Nan XX Kota Padang belum mampu memberikan pelayanan yang efisien kepada anggotanya.

Tabel 24

Skor Rasio Efisiensi Staf

\begin{tabular}{ccccc}
\hline Tahun & Rasio Efisiensi Staf (orang) & Nilai & Bobot Skor (\%) & Skor \\
\hline 2016 & 45 & 25 & 2 & 0,5 \\
2017 & 48 & 25 & 2 & 0,5 \\
2018 & 114 & 100 & 2 & 2,0 \\
\hline
\end{tabular}

Sumber : olahan data

\section{Rasio Likuiditas \\ Rasio Kas}

Tabel 25

Standar Perhitungan Rasio Kas

\begin{tabular}{lcccc}
\hline \multicolumn{1}{c}{ Rasio Kas $(\%)$} & Nilai & Bobot $(\%)$ & Skor & Kriteria \\
\hline$<14$ dan $>56$ & 25 & 10 & 2,5 & Tidak Likuid \\
$(14-20)$ dan $(46-56)$ & 50 & 10 & 5 & Kurang Likuid \\
$(21-25)$ dan $(35-45)$ & 75 & 10 & 7,5 & Cukup Likuid \\
$(26-34)$ & 100 & 10 & 10 & Likuid \\
\hline
\end{tabular}

Sumber: Perdep No: 07/Per/Dep.6/IV/2016

Setelah besarnya rasio diketahui, langkah selanjutnya yaitu pemberian skor terhadap rasio tersebut sesuai dengan Peraturan Deputi Bidang Pengawasan Kementerian Koperasi Dan UKM tahun 2016. Untuk skor rasio kas di "KSPPS Tanah Sirah Piai Nan XX Kota Padang” tahun 2016-2018 dapat dilihat dalam tabel 26. Hasil perhitungan menunjukkan selama tiga tahun terakhir mempunyai nilai skor rasio ini mendapat kategori baik. Ini berarti KSPPS Tanah Sirah Piai Nan XX Kota Padang memilki kas yang lancar untuk memenuhi kebutuhan anggotanya.

Tabel 26

Skor Rasio Kas

\begin{tabular}{ccccc}
\hline Tahun & Rasio Kas (\%) & Nilai & Bobot Skor (\%) & Skor \\
\hline 2016 & 45 & 25 & 10 & 2,5 \\
2017 & 33,15 & 100 & 10 & 10 \\
2018 & 44,01 & 75 & 10 & 7,5 \\
\hline
\end{tabular}

Sumber : olahan data 
Dwila Maresti dan Sriwahyuni Riza, Penilaian Kesehatan Keuangan Koperasi Berdasarkan Peraturan Deputi Bidang Pengawasan Kementerian Koperasi dan UKM RI NOMOR: 07/PER/DEP.6/IV/2016 pada KSPPS Tanah Sirah Piai Nan XX Kota Padang Periode 2016-2018

\section{Rasio Pembiayaan terhadap Dana yang Diterima}

Tabel 27

Standar Perhitungan Rasio Pembiayaan terhadap Dana yang Diterima

\begin{tabular}{ccccc}
\hline $\begin{array}{c}\text { Rasio Pembiayaan terhadap Dana yang } \\
\text { Diterima }(\boldsymbol{\%})\end{array}$ & Nilai & Bobot $(\boldsymbol{\%})$ & Skor & Kriteria \\
\hline$<50$ & 25 & 5 & 1,25 & Tidak Likuid \\
$51-75$ & 50 & 5 & 2,50 & Kurang Likuid \\
Cukup Likuid & Likuid \\
$76-100$ & 75 & 5 & 5,75 & 5 \\
\hline
\end{tabular}

Sumber: Perdep No: 07/Per/Dep.6/IV/2016

Skor rasio pembiayaan terhadap dana yang diterima di "KSPPS Tanah Sirah Piai Nan XX Kota Padang" tahun 2016-2018 dapat dilihat dalam tabel 28. Hasil perhitungan menunjukkan selama tiga tahun terakhir mempunyai nilai skor rasio ini mendapat kategori cukup likuid. Ini berarti KSPPS Tanah Sirah Piai Nan XX Kota Padang memiliki sejumlah dana dari simpanan yang mampu memenuhi kebutuhan anggotanya.

Tabel 28

Skor Rasio Pembiayaan terhadap Dana yang Diterima

\begin{tabular}{ccccc}
\hline \multirow{2}{*}{ Tahun } & $\begin{array}{c}\text { Rasio Pembiayaan terhadap } \\
\text { Dana yang Diterima (\%) }\end{array}$ & Nilai & Bobot Skor (\%) & Skor \\
\hline 2016 & 77,10 & 75 & 5 & 3,75 \\
2017 & 81,22 & 75 & 5 & 3,75 \\
2018 & 84,97 & 75 & 5 & 3,75 \\
\hline
\end{tabular}

Sumber : olahan data

Rasio Kemandirian dan Pertumbuhan

Rasio Rentabilitas Asset

Tabel 29

Standar Perhitungan Rasio Rentabilitas Asset

\begin{tabular}{ccccc}
\hline Rasio Rentabilitas Asset (\%) & Nilai & Bobot $(\boldsymbol{\%})$ & Skor & Kriteria \\
\hline$<5 \%$ & 25 & 3 & 0,75 & Rendah \\
$5-7,4$ & 50 & 3 & 1,50 & Kurang \\
$7,5-10$ & 75 & 3 & 2,25 & Cukup \\
$>10$ & 100 & 3 & 3,00 & Tinggi \\
\hline
\end{tabular}

Sumber: Perdep No: 07/Per/Dep.6/IV/2016

Setelah besarnya rasio diketahui, langkah selanjutnya yaitu pemberian skor terhadap rasio tersebut sesuai dengan Peraturan Deputi Bidang Pengawasan Kementerian Koperasi Dan UKM tahun 2016. Untuk skor rasio rentabilitas asset di "KSPPS Tanah Sirah Piai Nan XX Kota Padang" tahun 2016-2018 dapat dilihat dalam tabel 30. Hasil perhitungan menunjukkan selama tiga tahun terakhir mempunyai nilai skor rasio ini mendapat kategori rendah. Ini berarti KSPPS Tanah Sirah Piai Nan XX Kota Padang belum mampu memanfaatkan aset yang dimilikinya sehingga sisa hasil usaha yang dihasilkan pada akhir periode tahun berjalan menjadi kecil jika dibandingkan dengan total aset/aktiva yang dimiliki.

Tabel 30

Skor Rasio Rentabilitas Asset

\begin{tabular}{ccccc}
\hline Tahun & Rasio rentabilitas asset (\%) & Nilai & Bobot Skor (\%) & Skor \\
\hline 2016 & 0,44 & 25 & 3 & 0,75 \\
2017 & 0,41 & 25 & 3 & 0,75 \\
2018 & 0,50 & 25 & 3 & 0,75 \\
\hline
\end{tabular}

Sumber : olahan data 
Dwila Maresti dan Sriwahyuni Riza, Penilaian Kesehatan Keuangan Koperasi Berdasarkan Peraturan Deputi Bidang Pengawasan Kementerian Koperasi dan UKM RI NOMOR: 07/PER/DEP.6/IV/2016 pada KSPPS Tanah Sirah Piai Nan XX Kota Padang Periode 2016-2018

\section{Rasio Rentabilitas Modal Sendiri}

Tabel 31

Standar Perhitungan Rasio Rentabilitas Modal Sendiri

\begin{tabular}{ccccc}
\hline Rasio Rentabilitas Ekuitas (\%) & Nilai & Bobot $(\boldsymbol{\%})$ & Skor & Kriteria \\
\hline$<5 \%$ & 25 & 3 & 0,75 & Rendah \\
$5-7,4$ & 50 & 3 & 1,50 & Kurang \\
$7,5-10$ & 75 & 3 & 2,25 & Cukup \\
$>10$ & 100 & 3 & 3,00 & Tinggi \\
\hline
\end{tabular}

Sumber: Perdep No: 07/Per/Dep.6/IV/2016

Skor rasio rentabilitas modal sendiri di "KSPPS Tanah Sirah Piai Nan XX Kota Padang" tahun 2016-2018 dapat dilihat dalam tabel 33. Hasil perhitungan menunjukkan selama tiga tahun terakhir mempunyai nilai skor rasio ini mendapat kategori rendah. Ini berarti KSPPS Tanah Sirah Piai Nan XX Kota Padang belum dapat memanfaatkan modal sendiri yang dimiliki untuk menghasilkan sisa hasil usaha bagian anggota yang besar pada akhir periode tahun berjalan. Semakin efisien KSPPS Tanah Sirah Piai Nan XX Kota Padang dapat memanfaatkan modal sendiri yang dimilikinya maka kesejahteraan anggota dapat ditingkatkan karena sisa hasil usaha yang lebih besar dapat dihasilkan untuk anggota koperasi.

Tabel 32

Skor rasio rentabilitas modal sendiri

\begin{tabular}{ccccc}
\hline Tahun & Rasio rentabilitas asset (\%) & Nilai & Bobot Skor (\%) & Skor \\
\hline 2016 & 0,45 & 25 & 3 & 0,75 \\
2017 & 0,35 & 25 & 3 & 0,75 \\
2018 & 0,16 & 25 & 3 & 0,75 \\
\hline
\end{tabular}

Sumber : olahan data

\section{Rasio Kemandirian Operasional Pelayanan}

Tabel 33

Standar Perhitungan Rasio Kemandirian Operasional Pelayanan

\begin{tabular}{ccccc}
\hline Rasio Kemandirian Operasional (\%) & Nilai & Bobot (\%) & Skor & Kriteria \\
\hline$<100$ & 25 & 4 & 1 & Rendah \\
$100-125$ & 50 & 4 & 2 & Kurang \\
$126-150$ & 75 & 4 & 3 & Cukup \\
$>150$ & 100 & 4 & 4 & Tinggi \\
\hline
\end{tabular}

Sumber: Perdep No: 07/Per/Dep.6/IV/2016

Skor rasio kemandirian operasional pelayanan di “KSPPS Tanah Sirah Piai Nan XX Kota Padang” tahun 2016-2018 dapat dilihat dalam tabel 34. Hasil perhitungan menunjukkan selama tiga tahun terakhir mempunyai nilai skor rasio ini mendapat kategori kurang. Ini berarti KSPPS Tanah Sirah Piai Nan XX Kota Padang dalam memperoleh pendapatan usaha koperasi belum mampu menutupi semua biaya operasional koperasi dan menghasilkan sisa hasil usaha yang kecil pada akhir periode tahun berjalan. Nilai rasio dapat lebih ditingkatkan lagi jika koperasi, mampu menekan biaya operasional yang dikeluarkan, sehingga sisa hasil usaha yang dihasilkan pun dapat perlahan meningkat.

Tabel 34

Skor Rasio Kemandirian Operasional Pelayanan

\begin{tabular}{ccccc}
\hline Tahun & Rasio kemandirian operasional pelayanan (\%) & Nilai & Bobot Skor (\%) & Skor \\
\hline 2016 & 100,10 & 50 & 4 & 4 \\
2017 & 105,13 & 50 & 4 & 2 \\
2018 & 113,63 & 50 & 4 & 2 \\
\hline
\end{tabular}

Sumber : olahan data 
Dwila Maresti dan Sriwahyuni Riza, Penilaian Kesehatan Keuangan Koperasi Berdasarkan Peraturan Deputi Bidang Pengawasan Kementerian Koperasi dan UKM RI NOMOR: 07/PER/DEP.6/IV/2016 pada KSPPS Tanah Sirah Piai Nan XX Kota Padang Periode 2016-2018

\section{Jati diri Koperasi \\ Rasio Partisipasi Bruto}

Tabel 35

Standar Perhitungan Rasio Partisipasi Bruto

\begin{tabular}{ccccc}
\hline Rasio Partisipasi Bruto (\%) & Nilai & Bobot $(\boldsymbol{\%})$ & Skor & Kriteria \\
\hline$<25$ & 25 & 5 & 1,25 & Rendah \\
$25-49$ & 50 & 5 & 2,50 & Kurang \\
$50-75$ & 75 & 5 & 3,75 & Cukup \\
$>75$ & 100 & 5 & 5 & Tinggi \\
\hline
\end{tabular}

Sumber: Perdep No: 07/Per/Dep.6/IV/2016

Rasio partisipasi bruto ini dimaksudkan untuk mengukur kemampuan KSPPS dalam mengaktifkan anggotanya perihal simpan pinjam dan pembiayaan. Skor rasio partisipasi bruto di "KSPPS Tanah Sirah Piai Nan XX Kota Padang" tahun 2016-2018 dapat dilihat dalam tabel 36. Hasil perhitungan menunjukkan selama tiga tahun terakhir mempunyai nilai skor rasio ini mendapat kategori tinggi. Ini berarti KSPPS Tanah Sirah Piai Nan XX Kota Padang memiliki kontribusi anggota yang tinggi dalam penyediaan modal.

Tabel 36

Skor Rasio Partisipasi Bruto

\begin{tabular}{ccccc}
\hline Tahun & Rasio Partisipasi Bruto (\%) & Nilai & Bobot Skor (\%) & Skor \\
\hline 2016 & 100,50 & 100 & 5 & 5 \\
2017 & 138,73 & 100 & 5 & 5 \\
2018 & 100,13 & 100 & 5 & 5 \\
\hline
\end{tabular}

Sumber : olahan data

Rasio Partisipasi Ekonomi Anggota

Tabel 37

Standar Perhitungan Rasio Partisipasi Ekonomi Anggota

\begin{tabular}{ccccl}
\hline Rasio Partisipasi Ekonomi Anggota (\%) & Nilai & Bobot (\%) & Skor & Kriteria \\
\hline$<5$ & 25 & 5 & 1,25 & Tidak Bermanfaat \\
$5-7,99$ & 50 & 5 & 2,50 & Kurang Bermanfaat \\
$8-11,99$ & 75 & 5 & 3,75 & Cukup Bermanfaat \\
$>12$ & 100 & 5 & 5 & Bermanfaat \\
\hline
\end{tabular}

Sumber: Perdep No: 07/Per/Dep.6/IV/2016

Skor rasio partisipasi ekonomi anggota di "KSPPS Tanah Sirah Piai Nan XX Kota Padang” tahun 2016-2018 dapat dilihat dalam tabel 38. Hasil perhitungan menunjukkan dalam tiga tahun terakhir nilai skor rasio ini mendapat kategori bermanfaat. Ini berartipartisipasi anggota dalam penyediaan modal dalam bentuk simpanan kepada KSPPS menghasilkan manfaat atau sisa hasil usaha yang cukup besar untuk kesejahteraan anggota hanya pada tahun 2016 dan 2017. Penurunan yang signifikan terlihat pada tahun 2018.

Tabel 38

Skor Rasio Partisipasi Ekonomi Anggota

\begin{tabular}{ccccc}
\hline Tahun & Rasio Partisipasi Ekonomi Anggota (\%) & Nilai & Bobot Skor (\%) & Skor \\
\hline 2016 & 18,68 & 100 & 5 & 5 \\
2017 & 21,77 & 100 & 5 & 5 \\
2018 & 4,54 & 25 & 5 & 1,25 \\
\hline
\end{tabular}

Sumber : olahan data 
Dwila Maresti dan Sriwahyuni Riza, Penilaian Kesehatan Keuangan Koperasi Berdasarkan Peraturan Deputi Bidang Pengawasan Kementerian Koperasi dan UKM RI NOMOR: 07/PER/DEP.6/IV/2016 pada KSPPS Tanah Sirah Piai Nan XX Kota Padang Periode 2016-2018

\section{Kepatuhan Prinsip Syariah}

Tabel 39

Standar Perhitungan Kepatuhan Prinsip Syariah

\begin{tabular}{cccc}
\hline Positif & Nilai Kredit Bobot & Skor & Kriteria \\
\hline 1 & 1 & & Tidak Patuh Kurang Patuh Cukup Patuh \\
2 & 2 & $0-2,50$ & Patuh \\
3 & 3 & $2,51-5,00$ & \\
4 & 4 & $5,01-7,50$ & \\
5 & 5 & $7,51-$ & \\
6 & 6 & 10,00 & \\
7 & 7 & & \\
8 & 8 & & \\
9 & 9 & & \\
10 & 10 & & \\
\hline
\end{tabular}

Sumber: Perdep No: 07/Per/Dep.6/IV/2016

Skor kepatuhan pada prinsip syariah yang diberikan di "KSPPS Tanah Sirah Piai Nan XX Kota Padang” tahun 2016-2018 dapat dilihat dalam tabel 40. Hasil penilaian menunjukkan selama tiga tahun terakhir ditemukan KSPPS Tanah Sirah Piai Nan XX Kota Padang semakin meningkatkan kepatuhan akan prinsip syariah yang ada.

Tabel 40

Perhitungan Kepatuhan Prinsip Syariah

\begin{tabular}{cccc}
\hline Tahun & Bobot & Skor & Kriteria \\
\hline 2016 & 6 & 6 & Cukup Patuh \\
2017 & 7 & 7 & Patuh \\
2018 & 8 & 8 & Patuh \\
\hline
\end{tabular}

Sumber : olahan data

\section{Pembahasan}

Tabel 41.

Skor Penilaian Tingkat Kesehatan KSPPS Tanah Sirah Piai Nan XX Kota Padang

\begin{tabular}{|c|c|c|c|c|}
\hline \multirow{2}{*}{ No } & \multirow{2}{*}{ Aspek Komponen } & \multicolumn{2}{|c|}{ Tahun } & \multirow[b]{2}{*}{2018} \\
\hline & & 2016 & 2017 & \\
\hline \multirow[t]{4}{*}{1.} & Aspek Permodalan & & & \\
\hline & a. Rasio Modal Sendiri terhadap Total Aset & 5,00 & 5,00 & 5,00 \\
\hline & b. Rasio Kecukupan Modal (CAR) & 5,00 & 5,00 & 5,00 \\
\hline & Jumlah Skor Permodalan & 10,00 & $\mathbf{1 0 , 0 0}$ & 10,00 \\
\hline \multirow[t]{5}{*}{2.} & Aspek Kualitas Aktiva Produktif & & & \\
\hline & $\begin{array}{l}\text { a. Rasio Piutang dan Pembiayaan Bermasalah Terhadap Piutang } \\
\text { dan Pembiayaan }\end{array}$ & 2,50 & 10,00 & 2,50 \\
\hline & b. Rasio Portofolio Pembiayaan Berisiko & 5,00 & 5,00 & 1,25 \\
\hline & c. Rasio PPAP terhadap PPAPWD & 5,00 & 0,00 & 5,00 \\
\hline & Jumlah Skor KAP & 12,50 & 15,00 & 8,75 \\
\hline \multirow[t]{7}{*}{3.} & Aspek Manajemen & & & \\
\hline & a. Manajemen Umum & 2,50 & 3,00 & 3,00 \\
\hline & b. Manajemen Kelembagaan & 3,00 & 3,00 & 3,00 \\
\hline & c. Manajemen Permodalan & 0,60 & 1,80 & 2,40 \\
\hline & d. Manajemen Aktiva & 2,40 & 1,20 & 2,40 \\
\hline & e. Manajemen Likuiditas & 1,80 & 2,40 & 3,00 \\
\hline & Jumlah Skor Manajemen & 10,30 & 11,40 & 13,80 \\
\hline \multirow[t]{5}{*}{4.} & Aspek Efisiensi & & & \\
\hline & a. Rasio biaya operasional pelayanan terhadap partisipasi bruto & 2,00 & 1,00 & 2,00 \\
\hline & b. Rasio aktiva tetap terhadap total modal & 4,00 & 4,00 & 4,00 \\
\hline & c. Rasio efisiensi pelayanan & 0,50 & 0.50 & 2,00 \\
\hline & Jumlah Skor Efisiensi & $\mathbf{6 , 5 0}$ & $\mathbf{5 , 5 0}$ & 8,00 \\
\hline \multirow[t]{2}{*}{5.} & Aspek Likuiditas & & & \\
\hline & a. Rasio Kas dan Bank terhadap Kewajiban Lancar & 2,50 & 10,00 & 7,50 \\
\hline
\end{tabular}




\begin{tabular}{|c|c|c|c|c|}
\hline & b. Rasio pembiayaan yang diberikan terhadap dana yang diterima & 3,75 & 3,75 & 3,75 \\
\hline & Jumlah Skor Likuiditas & 6,25 & 13,75 & 11,25 \\
\hline & Aspek Kemandirian dan Pertumbuhan & & & \\
\hline & a. Rentabilitas Assets & 0,75 & 0,75 & 0,75 \\
\hline & b. Rentabilitas Modal Sendiri & 0,75 & 0,75 & 0,75 \\
\hline & c. Kemandirian Operasional Pelayanan & 2,00 & 2,00 & 2,00 \\
\hline \multirow{2}{*}{6.} & Jumlah Skor Kemandirian dan Pertumbuhan & $\mathbf{3 , 5 0}$ & $\mathbf{3 , 5 0}$ & 3,50 \\
\hline & Aspek Jatidiri Koperasi & & & \\
\hline \multirow{3}{*}{7.} & a. Rasio Pertisiapasi Bruto & 5,00 & 5,00 & 5,00 \\
\hline & b. Rasio Promosi Ekonomi Anggota & 5,00 & 5,00 & 1,25 \\
\hline & Jumlah Skor Jati Diri Koperasi & 10,00 & 10,00 & $\mathbf{6 , 2 5}$ \\
\hline \multirow[t]{3}{*}{8.} & Kepatuhan Prinsip Syariah & 6,00 & $\mathbf{7 , 0 0}$ & $\mathbf{8 , 0 0}$ \\
\hline & Total Skor Penilaian Kesehatan & 65,05 & $\mathbf{7 6 , 1 5}$ & 69,55 \\
\hline & Kategori & Cukup Sehat & Cukup Sehat & Cukup Sehat \\
\hline
\end{tabular}

Sumber : olahan data

Delapan aspek yang dinilai yaitu aspek modal, aspek kualitas, aspek manajemen, aspek efisiensi, aspek likuiditas dan aspek kemandirian, aspek jati diri dan kepatuahan syariah apabila dijumlah menghasilkan untuk tahun 2016 dengan nilai 65,05 tahun2017 dengan nilai 76,15 dan tahun 2018 dengan nilai 69,5, hal ini dinterpretasikan dengan Peraturan Deputi Bidang Pengawasan Kementerian Koperasi dan Usaha Kecil dan Menengah Republik Indonesia Nomor 07/Per/Dep.6/IV/2016 pada tabel 41, maka KSPPS Tanah Sirah Piai Nan XX Kota Padang berkategori Cukup Sehat. Hal tersebut karena KSPPS Tanah Sirah Piai Nan XX Kota Padang kurang memperhatikan kualitas aktiva produktif yang mengakibatkan rendahnya dalam membayar kewajiban koperasi dan juga kurang menekan adanya biaya operasional koperasi yang dikeluarkan sehingga menyebabkan sisa hasil usaha yang rendah.

\section{SIMPULAN}

Berdasarkan analisis data yang telah dilakukan berkaitan dengan tingkat kesehatan KSPPS Tanah Sirah Piai Nan XX Kota Padang, penilaian berdasarkan Peraturan Deputi Bidang Pengawasan Kementerian Koperasi dan Usaha Kecil dan Menengah Republik Indonesia Nomor 07/Per/Dep.6/IV/2016 maka dapat diambil kesimpulan KSPPS Tanah Sirah Piai Nan XX Kota Padang memiliki rasio permodalan yang sehat, tetapi untuk aspek kualitas aktiva produktif mengalami kemunduran yang signifikan ditahun 2018. Hal ini menjadi pehatian semua pihak KSPPS agar segera ditindaklanjuti. Untuk aspek manajemen terlihat KSPPS semakin membaik. Aspek efisiensi dalam tiga tahun terakhir, KSPPS berupaya terus meningkatkan efisiensinya baik itu operasional ataupun dalam investasi pada asset tetapnya agar menunjang pelayanan kepada anggotanya. Pada aspek likuiditas, walaupun dari analisa didapat kemampuan KSPPS cukup likuid, tetapi KSPPS masuk kategori yang masih membutuhkan dana, karena upaya KSPPS menyalurkan kas sangat besar pada produk pembiayaan yang berakibat rasio kas kecil. Anggota KSPPS, walaupun belum merasakan kebermanfaatan KSPPS sepenuhnya, tapi tetap ikut berpartisipasi dalam menumbuhkembangkan koperasi. Dalam beraktifitas KSPPS Tanah Sirah Piai Nan XX telah menerapkan prinsip syariah secara bertahap walaupun belum sepenuhnya.

\section{DAFTAR PUSTAKA}

Adi Angga Sukmana dan Sri Mulyati. 2015. Penilaian Kesehatan KJKS BMT BINAMAS. Jurnal Akuntansi dan Keuangan Islam Vol. 2, No. 2

Sundari, Siti. 2012. Faktor-Faktor yang Mempengaruhi Sustainabilitas Pertumbuhan Finansial Lembaga Keuangan Mikro Di Jawa Timur. Jurnal Manejemen dan Agribisnis, vol. 9, No. 1, 35

Hatta, Mohammad. 2015. Membangun Koperasi dan Koperasi Membangun. Jakarta. PT Kompas Media Nusantara.

Kasmir. 2012. Analisis Laporan Keuangan. Jakarta: PT. Raja Grafindo Persada.

Wira, V. (N.D.). Analisis Komponen Komponen Penilaian Kesehatan Koperasi Simpan Pinjam Dan Pembiayan Syariah (Kspps) Di Kota Padang.

Http://Repo.Polinpdg.Ac.Id/702/1/Ascnitech_2016_Nonrekayasa_-_Variyetmi_Wira\%2C_Gustati.pdf

(2016). Peraturan Deputi Bidang Pengawasan Kementerian Koperasi dan Usaha Kecil dan Menengah Republik Indonesia Nomor 07 Tahun 2016 Tentang Pedoman Penilaian Kesehatan Koperasi Simpan Pinjam dan Pembiayaan Syariah dan Unit Simpan Pinjam dan Pembiayaan Syariah Simpan Pinjam dan Pembiayaan Syariah.https://www.sumbarprov.go.id/images/1482118947-

Perdep07_2016_Penilaian_Kesehatan_KSP_Syariah.pdf 
Dwila Maresti dan Sriwahyuni Riza, Penilaian Kesehatan Keuangan Koperasi Berdasarkan Peraturan Deputi Bidang Pengawasan Kementerian Koperasi dan UKM RI NOMOR: 07/PER/DEP.6/IV/2016 pada KSPPS Tanah Sirah Piai Nan XX Kota Padang Periode 2016-2018

(2016). Peraturan Deputi Bidang Pengawasan Kementerian Koperasi dan Usaha Kecil dan Menengah Republik Indonesia Nomor 09 Tahun 2016 tentang Petunjuk Teknis Pemeriksaan Usaha Koperasi Simpan Pinjam dan Pembiayaan Syariah, dan Unit Simpan Pinjam dan Pembiayaan Syariah Koperasi.

(2017). Peraturan Menteri Koperasi dan Usaha Kecil dan Menengah Republik Indonesia Nomor 11 Tahun 2017 Tentang Pelaksanaan Kegiatan Usaha Simpan Pinjam dan Pembiayaan Syariah oleh Koperasi. https://www.sumbarprov.go.id/images/2018/01/file/PERMEN_NO_11_TAHUN_20172.pdf 